\title{
Brown Algae Himantothallus grandifolius (Desmarestiales, Phaeophyceae) Suppresses Proliferation and Promotes Apoptosis-Mediated Cell Death in Tumor Cells
}

\author{
Gabriela Gambato ${ }^{1,2}$, Érico G. Baroni ${ }^{3,4}$, Charlene S. C. Garcia ${ }^{2}$, Rafaele Frassini2, \\ Caroline 0. S. Frozza ${ }^{2}$, Sidnei Moura ${ }^{3}$, Cláudio M. P. Pereira5, Mutue T. Fujií, \\ Pio Colepicolo ${ }^{7}$, Ana Paula F. Lambert ${ }^{1}$, João A. P. Henriques' ${ }^{2}$, Mariana Roesch-Ely ${ }^{2 *}$ \\ ${ }^{1}$ Faculty of Pharmacy, University of Caxias do Sul, Caxias do Sul, Brazil \\ ${ }^{2}$ Laboratory of Genomics, Proteomics and DNA Repair, Biotechnology Institute, University of Caxias do Sul, \\ Caxias do Sul, Brazil \\ ${ }^{3}$ Laboratory of Biotechnology of Natural and Synthetic Products, Biotechnology Institute, University of Caxias \\ do Sul, Caxias do Sul, Brazil \\ ${ }^{4}$ Actually at Faculty of Chemical Engineering, University of Campinas, Campinas, Brazil \\ ${ }^{5}$ Institute of Chemistry and Geosciences, Federal University of Pelotas, Pelotas, Brazil \\ ${ }^{6}$ Botanical Institute, SMA, São Paulo, Brazil \\ ${ }^{7}$ Institute of Chemistry, University of São Paulo, São Paulo, Brazil \\ Email:
}

Received 13 February 2014; revised 14 March 2014; accepted 19 March 2014

Copyright (C) 2014 by authors and Scientific Research Publishing Inc.

This work is licensed under the Creative Commons Attribution International License (CC BY).

http://creativecommons.org/licenses/by/4.0/

(c) (i) Open Access

\section{Abstract}

Marine algae have been used as food since ancient times and today are consumed as a regular part of the diet. In this study, we hypothesized that $H$. grandifolius phlorotannins-enriched extract exerts cytotoxic selective effects against tumor cell lines promoting cell death trough apoptosis mechanisms. The aim of the present study is to characterize chemically and investigate the selective cytotoxic effect of the $\boldsymbol{H}$. grandifolius extract on epithelial tumour cell lines (A375, A549, Hep-2, HeLa) compared to non-malignant cell line (Hek-293), and evaluate possible molecular mechanisms involved in the programmed cell death pathway. High-resolution directly-infusion mass spectrometry (HR-DIMS) analysis with electrospray ionization (ESI) was performed in positive and negative mode. Cytotoxicity was evaluated through colorimetric assay and morphological altera-

\footnotetext{
"Corresponding author.
}

How to cite this paper: Gambato, G., et al. (2014) Brown Algae Himantothallus grandifolius (Desmarestiales, Phaeophyceae) Suppresses Proliferation and Promotes Apoptosis-Mediated Cell Death in Tumor Cells. Advances in Biological Chemistry, 4, 98-108. http://dx.doi.org/10.4236/abc.2014.42014 
tions were observed in giemsa stained cells after extract treatment. Apoptosis was further evaluated by annexin $V$ staining. Spectra showed peaks $m / z$ between 370 and 430 and molecular formula was defined upon isotopic ratio. Extract showed selectivity to the non-tumor line with enhanced cytotoxicity in tumor cells according to the concentration and exposure time. After $\mathbf{7 2} \mathbf{h}$ treatment, the HeLa strain was more susceptible to the extract, followed by lines Hep2, A375 and A549. Morphological changes by giemsa were observed after increased doses of extracts and staining for annexin $\mathrm{V}$ showed majority of tumor cells at early stages of the apoptotic process. Here, selective anti-tumor activity of extract taken from the alga $\mathrm{H}$. grandifolius was able to suppress proliferation and promote apoptosis-mediated cell death with induction of initial stages of apoptosis in different cell lines.

\section{Keywords}

Algae; Cytotoxicity; Apoptosis; Cancer; in Vitro

\section{Introduction}

Marine Natural Products (MNP) offer a rich chemical content of bioactive molecules that have become an important source of pharmacologically active metabolites [1]. The Antarctic Peninsula presents a wide variety of MNP, mainly marine algae. The western region of the Peninsula exhibits abundant macroalgae biomass, about $44 \%$ are endemic [2]. It is possible to classify macroalgae into three groups according to predominant photosynthetic pigments, storage products, and cell wall components: Green algae, Red algae, and Brown algae [3].

Marine algae have been used as food since ancient times, and today are consumed as a regular part of the diet, especially in Asian countries [4]-[6]. A derivate from the cyanobacteria group known as spirulina has been used as food taken its high amount of protein, among them the phycocyanin, and essential nutrients such as carotenoids, vitamins, and minerals [7]. Lipid extract from these group of algae also were able to exert antiinflammatory properties [8]. Macroalgae are currently used in the diet and may provide human beings with beneficial fatty acid once used as nutrient sources in food products [9]. The brown algae (class Phaeophyceae) are applied in treatment of several disorders in traditional medicine. Sargassum spp., belonging to family Sargassaceae, is a kind of edible brown algae that has been used as food and medicine commonly found in tropical and sub-tropical countries [10] [11].

The brown macroalgae Himantothallus grandifolius (A \& E Gepp) Zinova is an eukaryotic organism typically found in marine environment with geographical distribution in the Antarctic islands and subantarctic regions, being the prevalent species in regions such as the Potter Cove [12]. A recent study found the percentage distribution of Antarctic algae, and within the class Phaeophyceae, $H$. grandifolius has shown increased colonization and is, therefore, classified as endemic [13]. However, because it’s geographical localization, which implies in uncommon sun irradiation and cold weather, it is expected to be found active compounds as secondary metabolites. Iken et al. (2007) determined significant amounts of phlorotannins in H. grandifolius, but few studies have investigated their possible biological activity to date [2].

Recent reports suggest that brown algae could be a relevant source of anticancer compound [14]-[16]. Bioactive secondary metabolites such as sulfated polysaccharides, fucoxanthin and phenolic compounds were isolates from these species [14]. Marine algal polyphenol compounds, known as phlorotannins, are highly hydrophilic molecules found especially in brown algae [2] [17]. Several bioactivities have been reported for phlorotannins, such as antimicrobial, antiallergic, promoter of angiogenesis, tyrosinase inhibitory, anti-inflammatory, antioxidant and antitumor [15].

In this study, we hypothesized that $H$. grandifolius phlorotannins-enriched extract exerts cytotoxic selective effects against tumor cell lines promoting cell death trough apoptosis mechanisms. Algae have been reported to generate beneficial effects on health, thus our findings can help to increase the knowledge in the human nutrition field and life sciences research. The aim of the present study is to characterize chemically and investigate the selective cytotoxic effect of the $H$. grandifolius extract on epithelial tumour cell lines (A375, A549, Hep-2, HeLa) compared to non-malignant cell line (Hek-293), and evaluate possible molecular mechanisms involved in 
the programmed cell death pathway.

\section{Materials and Methods}

\subsection{Himantothallus grandifolius Extract (HgExt)}

Himantothallus grandifolius was collected in Punta Plaza $\left(62^{\circ} 5^{\prime} 34.82 " \mathrm{~S} \times 58^{\circ} 24^{\prime} 15.27^{\prime \prime} \mathrm{W}\right)$. The air dried material was triturated to obtain a uniform sample. $0.5 \mathrm{~g}$ of the sample was extracted with $15 \mathrm{~mL}$ of acetone: water (1:1) for $15 \mathrm{~min}$ assisted by an ultrasound bath at $55 \mathrm{~Hz}$. The liquid phase was separated and evaporated under vacuum. The dry extract was dissolved in ethanol $20 \%$ and filter through a $0.2 \mu \mathrm{m}$. The extract was further diluted with cell culture medium. The final ethanol concentration used was $1 \%$ of total volume of the medium in all treatments, including the negative control group.

\subsection{Chemical Analysis}

The dry extract was dissolved in a solution of $50 \%(\mathrm{v} / \mathrm{v})$ chromatographic grade acetonitrile (Tedia, Fairfield, OH, USA), $50 \%(\mathrm{v} / \mathrm{v})$ deionized water and $0.1 \%$ formic acid. The solutions were infused directly individually or with HPLC (Shymadzu ${ }^{\circledR}$ ) assistance into the ESI source by means of a syringe pump (Harvard Apparatus) at a flow rate of $10 \mu \mathrm{L} \cdot \mathrm{min}^{-1}$. ESI(+)-MS and tandem ESI(+)-MS/MS were acquired using a hybrid high-resolution and high accuracy (5 $\mu \mathrm{L} / \mathrm{L})$ microTOF-Q II $(Q-T O F)$ mass spectrometer (Bruker Scientific ${ }^{\circledR}$ ) under the following conditions: capillary and cone voltages were set to $+3500 \mathrm{~V}$ and $+40 \mathrm{~V}$, respectively, with a de-solvation temperature of $100^{\circ} \mathrm{C}$. For ESI(+)-MS/MS, the energy for the collision induced dissociations (CID) was optimized for each component. Diagnostic ions in fraction were identified by combinations of isotopic ratio, exact mass and fragmentation pathway in its ESI(+)-MS/MS and ESI(-)-MS/MS. For data acquisition and processing, TOF control (Bruker Scientific) was used. The data were collected in the $m / z$ range of $70-1000$ at the speed of two scans per second, providing the resolution of 50,000 (FWHM) at $\mathrm{m} / \mathrm{z} 200$. No important ions were observed below $m / z 100$ or above $m / z$ 800, therefore ESI(+)-MS data is shown in the $m / z 100-800$ range.

\subsection{Cell Cultures}

The immortalized human epithelial cells lines of malignant melanoma (A375-BCRJ 0278), lung carcinoma (A549—BCRJ 0033), cervix adenocarcinoma (HeLa_BCRJ 0100), larynix carcinoma (Hep-2—BCRJ 0101) and non-malignant human embryonic kidney (Hek-293_BCRJ 0009) were purchased from Rio de Janeiro Cell Bank, imported from ATCC. These cells were maintained in Dulbecco's Modified Eagle Medium (DMEM) supplemented with $10 \%$ fetal bovine serum (Gibco BRL; Life Technologies) and 1\% penicillin-streptomycin (Sigma-Aldrich $^{\circledR}$ ) in a humidified $5 \% \mathrm{CO}_{2}$ atmosphere at $37^{\circ} \mathrm{C}$.

\subsection{Cell Viability Assay}

Cytotoxicity was assessed by MTT (3-[4,5-dimethylthiazol-2-yl]-2,5 diphenyl tetrazolium bromide) method. Therefore cells were seeded in 96-well plates at a density of $2 \times 10^{4}$ cells $/ \mathrm{cm}^{2}$. After $24 \mathrm{~h}$ incubation, the cells were treated with increasing concentrations of HgExt $(100-500 \mu \mathrm{g} / \mathrm{mL})$ for 24,48 and $72 \mathrm{~h}$. Ethanol 1\% was added to medium as a negative control. MTT solution $(0.4 \mathrm{mg} / \mathrm{mL})$ was added after treatment and incubated for $2 \mathrm{~h}$, followed by dimethyl sulfoxide incubation. The optical density (OD) was measured at $570 \mathrm{~nm}$. The cell viability rate $(\%)$ was calculated as follows: (OD of the treated group/OD control group) $\times 100$. The results represent the averages of 3 independent experiments performed in triplicate.

\subsection{Morphological Characterization and Detection of Cell Apoptosis}

Cells were seeded into 24-well plates containing coverslips. After $24 \mathrm{~h}$ incubation, the cells were treated with HgExt extract for $48 \mathrm{~h}$ at $\mathrm{IC}_{50}(\mu \mathrm{g} / \mathrm{mL})$, and stained with Accustain ${ }^{\circledR}$ Giemsa Stain (Sigma-Aldrich ${ }^{\circledR}$ ) according standard giemsa procedure established by the supplier. The cell morphological changes of treated and nontreated cells (negative control) were observed and photographed under a light microscope at $\times 200$ (Olympus BX43). After treatment, the cells were incubated with $2.5 \mu \mathrm{g} / \mathrm{mL}$ of Annexin $\mathrm{V}$ (abcam ${ }^{\circledR}$-ab14196) primary antibody diluted in biding buffer (Hepes $10 \mathrm{mM}, \mathrm{NaCl} 150 \mathrm{mM}, \mathrm{KCl} 5 \mathrm{mM}, \mathrm{MgCl}_{2} 1.8 \mathrm{mM}, \mathrm{CaCl}_{2} \mathrm{pH}=7,4$ ) for 30 minutes. They were washed once with binding buffer an then incubate with $2.5 \mu \mathrm{g} / \mathrm{mL}$ Dylight ${ }^{\circledR} 488$ (ab- 
cam $^{\circledR}$ —ab115637) secondary antibody. The cells in the late apoptosis or necrosis were staining with propidium iodate (PI) (Sigma-Aldrich ${ }^{\circledR}$ - P4170). Briefly, they were fixed with formalin $4 \%$ for 15 minutes and then mounted with antifade mounting media. The apoptosis was analyzed by fluorescent microscopy at $\times 400$ (Olympus BX43). The percentage of cells undergoing early (annexin V positive) or late (annexin V + PI positive) apoptosis was estimated by counting 200 cells or twenty fields.

\subsection{Statistical Analysis}

All the experiments were repeated at least three times and the results were expressed as mean \pm standard deviation. The statistical differences were analyzed using one-way ANOVA followed by a Tukey post hoc. Values of $\mathrm{p}<0.05$ were considered significant.

\section{Results}

\subsection{Chemical Characterization of $H_{\text {. }}$ grandifolius Macroalgae Extract}

Considering the sample complexity, it is necessary a robust and sensitive tool with good resolution to generate chemical information. To date, there are no complete studies about the chemical composition for Antarctic algae as $H$. grandifolius. Here, high-resolution directly-infusion mass spectrometry (HR-DIMS) analysis with electrospray ionization (ESI) was performed, which has been an important device to characterize and identify complex natural metabolites. The instrument accurate mass measurement gives the exact mass, the isotopic ratio and the of parent fragmentation pathway. The extract was tested in positive and negative mode. According to this information, the elemental composition was defined and is shown in Table 1. Since the widely accepted accuracy threshold for confirmation of elemental compositions was established as 5 ppm [18], we have considered compounds bellow this threshold, providing highly reliable identification of the target compounds.

In negative mode the results indicate presence of alcohols because these compounds suffer easy ionization. D-Mannitol, D-Glucitol, Galactitol ( $F W \mathrm{C}_{6} \mathrm{H}_{14} \mathrm{O}_{6}, \mathrm{~m} / \mathrm{z}$ 182.0730), all previously isolated by marine algae, are the probable compounds presented here [19]. In positive mode, several compounds have been identified in its molecular formula and are listed in Table 1. The full mass spectrum is shown in Figure 1(a), with representative compounds with peaks showing $\mathrm{m} / \mathrm{z}$ between 370 and 430 . Highlighted is the isotopic ratio, which was used for molecular formula definition.

On the other hand, important information can be obtained from fragmentation pathway. For example, the mass loses with $\mathrm{m} / \mathrm{z} 177.0327$ (394.0917 - 217.0590) and 32.9720 (264.0797 - 231.1077), demonstrates the presence of glycosides pattern and sulfur, respectively. In mode MS-2 the compound with $\mathrm{m} / \mathrm{z} 426.0601$ revealed the fragmentation with $\mathrm{m} / \mathrm{z} 243.0467\left(\mathrm{C}_{14} \mathrm{H}_{11} \mathrm{O}_{2} \mathrm{~S}\right.$ diff. $\left.5.24 \mathrm{ppm}\right)$, which corroborates this information. The occurrence of sulfated glycosides from Antarctic algae had already been reported by Berteau et al. [20]. Important information was observed by the peaks with $\mathrm{m} / \mathrm{z} 700$ and 400 fragmentation, which can be defined as chlorogenic acid $\left(\mathrm{C}_{16} \mathrm{H}_{18} \mathrm{O}_{9}, \mathrm{~m} / \mathrm{z}\right.$ 355.0977) in Figure 1(b). The presence of this compound in algae has been determined by Onofrejova et al. [21]. Nevertheless, the structural elucidation of some compounds by its MS spectrum is not trivial and for complete deduction more studies are required. In this way, the isolation of the compounds and chemical structures information will be done by other spectroscopic methods.

\subsection{Effect of $H$. grandifolius Extract on Cell Cytotoxicity}

For cytotoxic analysis MTT assay was performed based on the conversion of MTT into formazan crystals by living cells. This assay is widely used for measuring cytotoxic potential of drugs on cell lines or primary patient cells. Figure 2 shows the cytotoxic effect of HgExt in the viability of A375 (A), A549 (B), HeLa (C) and Hep-2 (D) cells. For all tumor lines analyzed, cell viability was decreased in a concentration and time-dependent manner. H. grandifolius macroalgae extract was most effective on $72 \mathrm{~h}$ treatment compared to $24 \mathrm{~h}$ and $48 \mathrm{~h}$. The half maximal inhibitory concentration $\left(\mathrm{IC}_{50}\right.$ ) obtained are listed in Table 2. HeLa cells were more susceptible to HgExt than other cells lines, followed by Hep2, A375 and A549 at all different incubation times of treatment. Non-tumor cell line Hek-293 was not sensitive to the extract, presenting $100 \%$ of survival at the highest HgExt concentration tested $(500 \mu \mathrm{g} / \mathrm{mL}$ ). The results presented in Figure 3 are related to $48 \mathrm{~h}$ treatment and demonstrated that all tumor cell lines responded to the treatment with HgExt in a similar way, suggesting a common extract mechanism of action. 
Table 1. High-resolution directly-infusion mass spectrometry (HR-DIMS) analysis with electrospray ionization (ESI) was performed in positive and negative mode. Diagnostic ions in fraction were identified by combinations of isotopic ratio, exact mass and fragmentation pathway. The data were collected in the $\mathrm{m} / \mathrm{z}$ range of $70-1000$, providing the resolution of 50,000 (FWHM) at $m / z$ 200. No important ions were observed below $\mathrm{m} / \mathrm{z} 100$ or above $\mathrm{m} / \mathrm{z} 800$.

\begin{tabular}{|c|c|c|c|c|c|}
\hline Entry & $\begin{array}{l}\text { Precursor } \\
\text { Ion } m / z(\%)\end{array}$ & Isotopic (\%) & $\begin{array}{l}\text { Elem. } \\
\text { Comp. }\end{array}$ & $\begin{array}{l}\text { Diff. } \\
\text { ppm }\end{array}$ & Fragmentation (\%) \\
\hline \multicolumn{6}{|c|}{ ESI-MS (+) } \\
\hline 1 & 180.0867 & $181.0712(6.7)$ & $\mathrm{C}_{6} \mathrm{H}_{14} \mathrm{NO}_{5}$ & 2.76 & $\begin{array}{l}163.0389(100) ; 126.5575(76) ; \\
116.0699 \text { (55); } 83.7065 \text { (92). }\end{array}$ \\
\hline 2 & 372.1115 & $\begin{array}{l}\text { 373.1117 (16.9); } 374.1049 \\
\quad(7.8) ; 375.0855 \text { (1.1). }\end{array}$ & $\mathrm{C}_{13} \mathrm{H}_{24} \mathrm{O}_{10} \mathrm{~S}$ & 0.05 & $\begin{array}{c}292.0816 \text { (80); } 264.0797 \text { (55); } 231.1077 \text { (100); } \\
\text { 204.0616 (45); } 147.0450 \text { (32). }\end{array}$ \\
\hline 3 & 388.1029 & $\begin{array}{l}\text { 389.1071 (16.5); } 390.1012 \\
\text { (5.8); } 391.1000(2.2)\end{array}$ & $\mathrm{C}_{19} \mathrm{H}_{18} \mathrm{NO}_{8}$ & 0.88 & $\begin{array}{l}292.0791 \text { (25); } 264.0488 \text { (15); } 236.0506 \text { (20); } 232.0775 \\
\quad(100) ; 204.0617 \text { (40); } 163.0390 \text { (15); } 117.0378(17)\end{array}$ \\
\hline 4 & 394.0917 & $\begin{array}{l}395.0959 \text { (16.1); } 396.0822 \\
\text { (8.8); } 397.0698(1.2)\end{array}$ & $\mathrm{C}_{13} \mathrm{H}_{20} \mathrm{~N}_{3} \mathrm{O}_{9} \mathrm{~S}$ & 0.82 & $\begin{array}{l}\text { 381.6149 (10); } 338.5052 \text { (82); } 329.0044 \text { (35); } 280.0494 \\
\text { (38); } 267.1260 \text { (20); } 217.0590 \text { (75); } 204.0616 \text { (20); } \\
\text { 198.0309 (60); } 186.0499 \text { (100); } 149.0175 \text { (22) }\end{array}$ \\
\hline 5 & 410.0807 & $\begin{array}{l}411.0814 \text { (17.1); } 412.0725 \\
\text { (9.5); } 413.0768(1.6)\end{array}$ & $\mathrm{C}_{12} \mathrm{H}_{20} \mathrm{~N}_{5} \mathrm{O}_{7} \mathrm{~S}_{2}$ & 0.70 & $\begin{array}{l}358.7672 \text { (10); } 346.0921 \text { (100); } 319.0593 \text { (15); } \\
260.0555 \text { (25); } 250.0646 \text { (15); } 202.0504 \text { (32) }\end{array}$ \\
\hline 6 & 426.0601 & $\begin{array}{l}427.0637 \text { (15.95); } 428.0573 \\
\text { (14.44); } 429.0576(2.21) .\end{array}$ & $\mathrm{C}_{14} \mathrm{H}_{22} \mathrm{~N}_{2} \mathrm{O}_{7} \mathrm{~S}_{3}$ & 2.78 & $\begin{array}{l}362.1954 \text { (22); } 342.0471 \text { (30); } 301.0595 \text { (27); } \\
268.0621 \text { (70); } 243.0467 \text { (35); } 222.9053 \text { (95) }\end{array}$ \\
\hline 7 & 765.1848 & $\begin{array}{l}766.1849 \text { (32.50); } 767.1730 \\
\text { (19.61); } 768.1866 \text { (9.23). }\end{array}$ & $\mathrm{C}_{28} \mathrm{H}_{39} \mathrm{~N}_{5} \mathrm{O}_{16} \mathrm{~S}_{2}$ & 1.93 & 410.0843 (15); 394.0855 (100); 177.3096 (65) \\
\hline 8 & 781.1631 & $\begin{array}{l}782.1873 \text { (35.16); } 783.1733 \\
\text { (24.43); } 784.1633 \text { (9.22). }\end{array}$ & $\mathrm{C}_{30} \mathrm{H}_{40} \mathrm{~N}_{2} \mathrm{O}_{16} \mathrm{~S}_{3}$ & 1.64 & 725.9975 (5); 426.0602 (5); 410.0763 (100) \\
\hline 9 & 797.1570 & $\begin{array}{l}798.1835(41.80) \\
799.1835(12.31)\end{array}$ & $\mathrm{C}_{30} \mathrm{H}_{40} \mathrm{~N}_{2} \mathrm{O}_{17} \mathrm{~S}_{3}$ & 0.33 & 426.0602 (60); 410.0843 (25); 119.9584 (5) \\
\hline \multicolumn{6}{|c|}{ ESI-MS (-) } \\
\hline 10 & 181.0720 & $182.0730(7.33)$ & $\mathrm{C}_{6} \mathrm{H}_{14} \mathrm{O}_{6}$ & 4.34 & \\
\hline 11 & 217.0496 & $218.0554(8.66)$ & $\mathrm{C}_{12} \mathrm{H}_{9} \mathrm{O}_{4}$ & 2.23 & \\
\hline
\end{tabular}

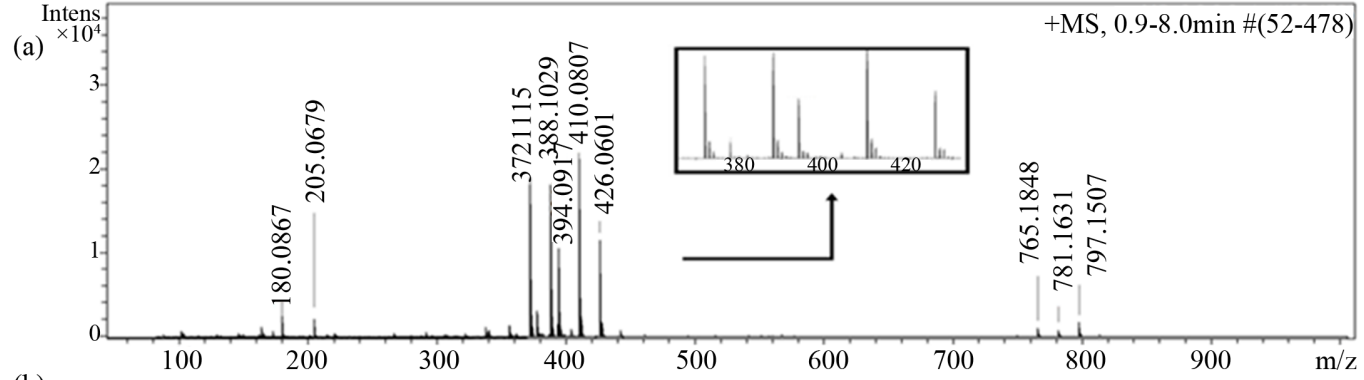

(b)

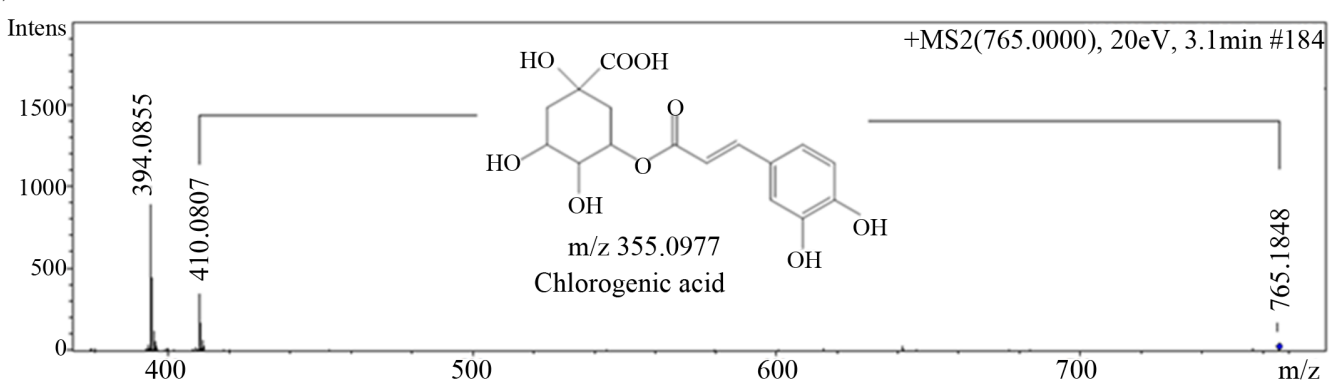

Figure 1. Spectra from dry extract dissolved in chromatographic grade solution. The solutions were infused directly, individually or with HPLC assistance into the ESI source by means of a syringe pump. AFull mass spectra in positive mode, several compounds have been identified in its molecular formula with representative compounds with peaks showing $\mathrm{m} / \mathrm{z}$ between 370 and 430 . Highlighted is the isotopic ratio, which was used for molecular formula definition. B-Peaks with $\mathrm{m} / \mathrm{z} 700$ and 400 fragmentation can be defined as chlorogenic acid $\left(\mathrm{C}_{16} \mathrm{H}_{18} \mathrm{O}_{9}, \mathrm{~m} / \mathrm{z}\right.$ 355.0977). 
(a)

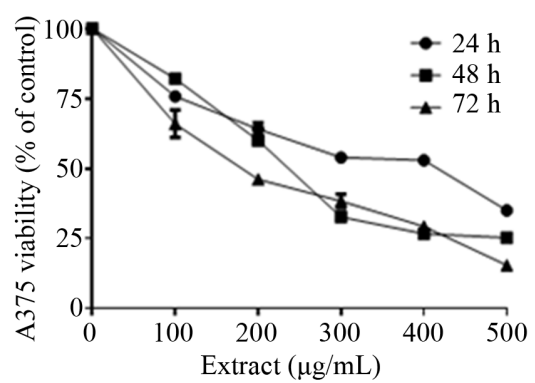

(c)

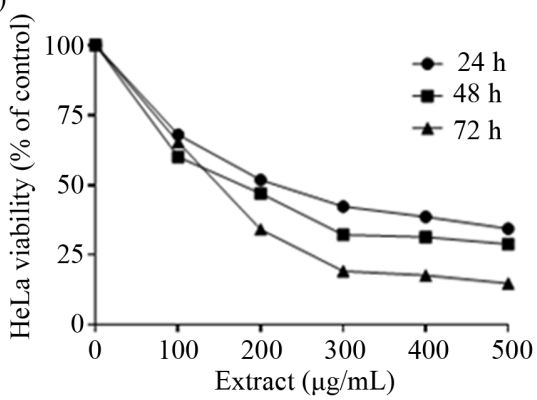

(b)

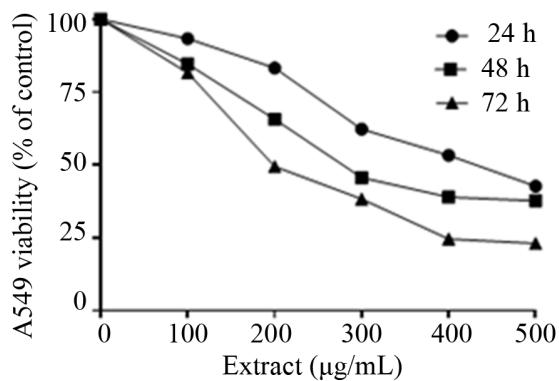

(d)

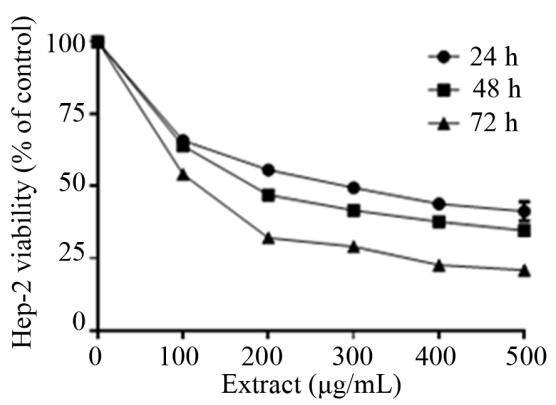

Figure 2. Cells were treated for 24, 48 and 72 h with HgExt at 100, 200, 300, 400 and 500 $\mu \mathrm{g} / \mathrm{mL}$. Bars represent mean \pm SD. A: A375 cell line. B: A549 cell line. C: HeLa cell line. D: Hep-2 cell line.

Table 2. Experiments were repeated in triplicates and results were expressed as mean \pm standard deviation. The statistical differences were analyzed using one-way ANOVA followed by a Tukey post hoc. Values of $\mathrm{p}<0.05$ were considered significant. Different superscript letters indicate significant differences between treatment time (hours) of in each cell line. Different superscript symbols indicate significant differences between cell lines for each time analyzed.

\begin{tabular}{|c|c|c|c|c|}
\hline & & \multicolumn{3}{|c|}{$\mathrm{IC}_{50}(\mu \mathrm{g} / \mathrm{mL})$} \\
\hline & & $24 \mathrm{~h}$ & $48 \mathrm{~h}$ & $72 \mathrm{~h}$ \\
\hline \multirow{5}{*}{ 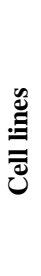 } & A375 & $348.30 \pm 8.75^{\mathrm{a} \#}$ & $214.93 \pm 4.04^{\mathrm{b} \#}$ & $165.37 \pm 9.08^{\mathrm{cH}}$ \\
\hline & A549 & $528.03 \pm 2.99^{\text {ał }}$ & $312.77 \pm 3.30^{\mathrm{b} \ddagger}$ & $197.83 \pm 2.53^{c \neq}$ \\
\hline & HeLa & $230.40 \pm 2.43^{\mathrm{a}^{*}}$ & $167.57 \pm 4.97^{\mathrm{b}^{*}}$ & $111.43 \pm 1.02^{\mathrm{c}}$ \\
\hline & Нер-2 & $280.17 \pm 5.40^{\mathrm{a}}$ & $210.03 \pm 3.04^{\mathrm{b} \#}$ & $114.10 \pm 1.59^{\mathrm{c}}$ \\
\hline & Hek-293 & $\geq 500$ & $\geq 500$ & $\geq 500$ \\
\hline
\end{tabular}

\subsection{Effect of H. grandifolius Extract on the Morphology of Cells and Induction of Apoptosis}

Detachment and shrinkage of cell structure could be observed in all lines tested. Morphologically changes of cells were more evident after $48 \mathrm{~h}$ of HgExt at $\mathrm{IC}_{50}(\mu \mathrm{g} / \mathrm{mL})$ compared to the negative control. Signaling to death at early stages of apoptosis was a major event in cell treated with HgExt compared to the untreated control group (Figure 4). Here, early apoptosis (Annexin V positive) presented significant higher expression compared to late apoptosis events (Annexin V and PI positive) for all cells investigated (Figures 4(a)-(d)).

\section{Discussion}

Himantothallus grandifolius extract obtained in this study present a novel and complex chemical characterization and important cytotoxic effect against tumor cell lines. To date this is the first report that investigates a crude extract obtained from brown algae showing an important biological activity. It is known that cancer is the second major cause of death worldwide, with increasing death rate every year [22]. Thus, focusing on new drugs 
(a)

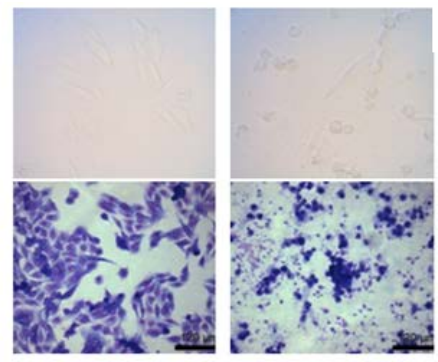

(c)
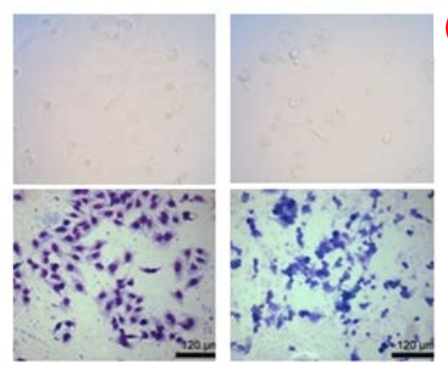

(b)

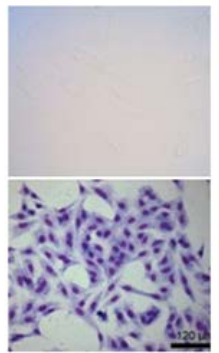

(d)

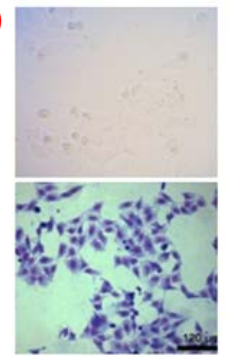

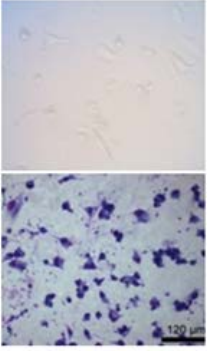

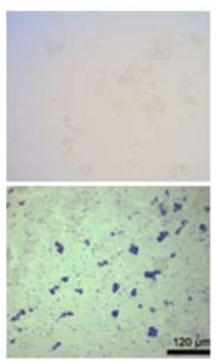

Figure 3. Cells treated for $48 \mathrm{~h}$ with negative control and HgExt at $\mathrm{IC}_{50}$ $(\mu \mathrm{g} / \mathrm{mL})$. Living (none fixed) cells are represented at first lines and stained fixed cell with Giemsa at second lines. A: A375 cell line. B: A549 cell line. C: HeLa cell line. D: Hep-2 cell line. First columns are control groups and second columns are represented as treated groups. Photomicrographs were taken under light microscopy (200×).

(a)

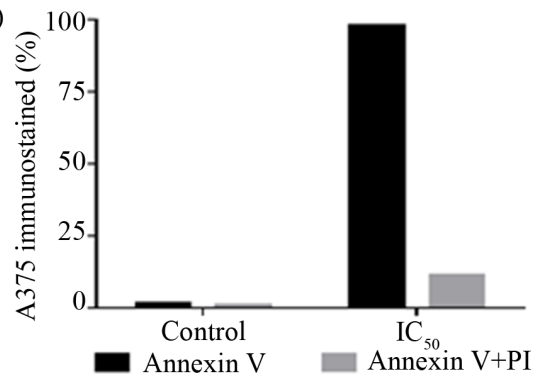

(c)

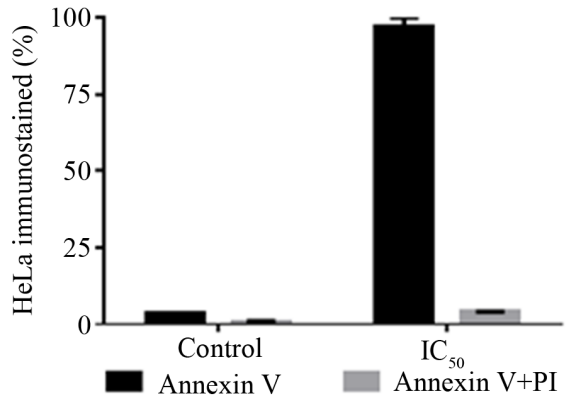

(b)

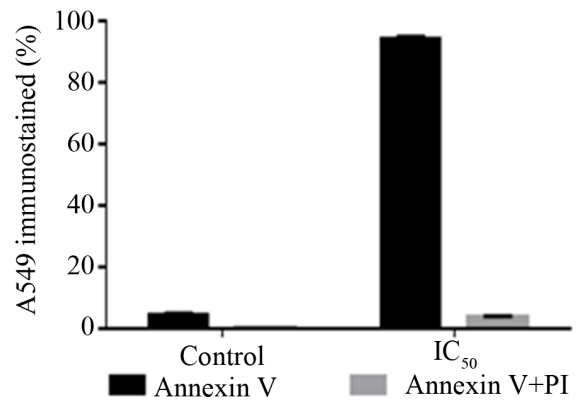

(d)

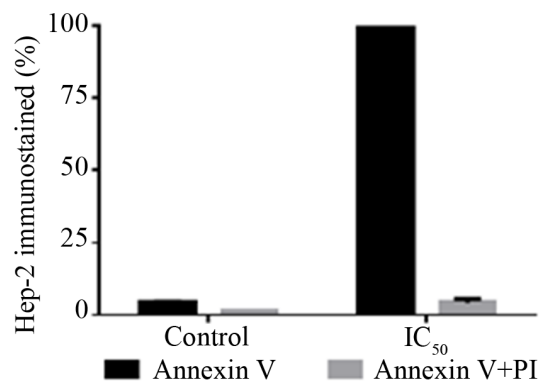

Figure 4. Percent of cells immunostained in early (Annexin V positive) or late apoptosis (Annexin V positive + PI positive) events. Results were obtained from three independent experiments expressed in median \pm SD. A: A375 cell line. B: A549 cell line. C: HeLa cell line. D: Hep-2 cell line.

of natural products that contribute to prevention strategies and treatment are very important [23]. Many vitamins from seaweed are essential due to its biochemical functions and antioxidant activity and also as health benefits such as decreasing of blood pressure, prevention of cardiovascular diseases, and reducing the risk of cancer [24]. 
Between 1998 and 2006, 592 marine natural products were investigated for its activity in pharmacology studies [1]. Cytotoxic studies using total extract obtained from a variety of algae have demonstrated that brown algae are a potential source of compounds presenting biological activities on tumor cells [15] [16] [25]. The results here presented with acetone extraction at different treatment times (24 h, 48 h, 72 h) showed IC 50 values ranging from $111.43 \mu \mathrm{g} / \mathrm{mL}$ to $528.03 \mu \mathrm{g} / \mathrm{mL}$ for the tumor cells lines analyzed. Other studies based on tumor activity of algae extracts on cancer cells reported similar IC $_{50}$ values. Colpomenia sinuosa (Mertens ex Roth) Derbès \& Solier (brown algae) methanol extract against HT-29 and Caco-2 colon adenocarcinoma cells lines $\mathrm{IC}_{50}$ showed greater $\mathrm{IC}_{50}(>1000 \mu \mathrm{g} / \mathrm{mL})$ [25]. A study with red algae Gracilaria tenuistipitata C.F. Chang \& B.M. Xia using methanol extraction against Ca9-22 oral cancer cells presented $\mathrm{IC}_{50} 326 \mu \mathrm{g} / \mathrm{mL}$ [26], very close to the ones here reported. A green algae Ulva lactuca Linnaeus (as U. fasciata) extracted with ethanol showed $50 \%$ growth inhibition for HCT 116 colon cancer cells at concentration of $200 \mu \mathrm{g} / \mathrm{ml}$ [27].

The selective induction of cell death is very important in chemotherapy to decreases possible side effects [23]. The HgExt showed no cytotoxic effects to Hek-293 cell line at all concentrations and incubation time tested. The differences of cytotoxicity from tumor and non-tumor lines are related to the ultrasound assisted extraction method, optimized to yield higher amounts of polyphenols (data not shown). Phlorotannins purified from others brown algae such as Ecklonia sp. has shown cytocompatible effects to human fetal lung fibroblasts cell line (MRC-5) [28] and macrophage-like form cell (THP-1 cell) [15]. A recent report using dieckol, an isolated compound from Ecklonia stolonifera Okamura algae extracts, also presented more selective effects to Hek-293 compared to a tumor cell line Hep3B [29].

Here, the chlorogenic acid (CHL) was defined as a molecule found in the extract obtained from the algae $H$. grandifolius. CHL has been attributed to have chemopreventive properties, modulating several mechanisms involved in the carcinogenesis process. CHL was able to inhibit metalloproteinases MMP-9 [30], microsomal glucose-6-phosphate translocase of U-87 of brain tumor-derived glioma cells [31] and inhibit proliferation of A549 human cancer cells due to the inhibitory effects on TPA- or NF-B, Activator Protein-1, and MAPK signaling [32]. Recently, the chlorogenic acid was shown to be able to inhibit tumor progression by changing gene expression involved in immune pathways [33].

The cytotoxic effects here observed also promoted changes in the morphology of cells and induction of cell death. Kerr \& Wyllie (1972) were the first authors that described such morphological features [34]. It is known that changes in cell morphology are related to physiological and pathological modifications by a variety of environmental stimuli. Apoptosis, autophagy and necrosis are the three main forms of cell death, easily distinguished by their morphological peculiarities [35]. Giemsa staining analyzes cell morphology using a simple colorimetric technique that gives a good high-contrast polychromatic stain. The typical morphology of apoptosis could be observed by Giemsa staining in all tumor cell lines here investigated treated with HgExt (IC ${ }_{50}$ for 48 h). Apoptosis is a programmed form of cell death observed in tissues during development and maintains tissue homeostasis through elimination of excessive or injured cells [35] [36]. Recent studies have shown that several bioactive compounds obtained from algae induced tumor cell death by apoptotic mechanism [14] [16] [37]. However, our study is pioneer in demonstrating these morphological changes through in situ analysis induced by the extract obtained from $H$. grandifolius.

The exposure of phosphatidylserine (PS) at the outer leaflet of the plasma membrane serves a physiological role in the recognition and subsequent removal of the dying cell by means of phagocytosis [38]. PS exposure during apoptosis seems to be a phenomenon during programmed cell death, not limited to mammalian cells, but also occurring in insect and plant cells [39]. The annexin V distribution observed in the tumor cells here investigated revealed that apoptosis was induced in a significant manner in all cell lines treated with the HgExt in comparison with the control group. The early apoptosis (Annexin V positive) event was significantly expressed compared to late apoptosis/necrosis (Annexin V + PI positive). Similar studies using apoptotic parameters revealed apoptotic mechanisms with total methanolic extract of red algae Gracilaria tenuistipitata [26], and isolated compounds like sargaquinoic acid from the brown algae Sargassum incisifolium (Turner) C. Agardh (as Sargassum heterophyllum) [40], and low-molecular-weight fucoidan obtained from Cladosiphon navae-caledoniae Kylin [16] [41]. It is known that tumor resistance to apoptotic cell death is a hallmark of cancer and that election of drugs which promote and induce apoptosis are desired. Many therapeutic agents for cancer, such as cisplatin, paclitaxel, isothiocyanate and adriamycin, have been reported to eliminate tumor cells by inducing apoptotic cell death [42] [43]. 


\section{Conclusion}

In conclusion, MNP have been only recently exploited and investigated as molecules that present promising antitumor activities. Algae have been reported to generate beneficial effects on health, thus we believe that our findings can help to increase the knowledge in the human nutrition field and life sciences research. It is essential to identify bioactive molecules in different extract, isolating compounds and determining whether the cytotoxic activity enhances with the isolated molecules or if it is a synergistic activity between compounds. Here, selective antitumor activity of extract taken from the alga $\mathrm{H}$. grandifolius was able to suppress proliferation and promote apoptosis-mediated cell death with induction of initial stages of apoptosis in different cell lines. Given the chemical complexity of the extract and the lack of material found in the literature for this sort of brown macroalgae, more studies are necessary for better understanding what molecules are bioactive and which pathways are involved in programmed cell death.

\section{Acknowledgements}

We thank CNPq at Programa Antártico Brasileiro (PROANTAR).

\section{References}

[1] Glaser, K.B. and Mayer, A.M. (2009) A Renaissance in Marine Pharmacology: From Preclinical Curiosity to Clinical Reality. Biochemical Pharmacology, 78, 440-448. http://dx.doi.org/10.1016/j.bcp.2009.04.015

[2] Iken, K., Amsler, C.D., Hubbard, J.M., McClintock, J.B. and Baker, B.J. (2007) Allocation Patterns of Phlorotannins in Antarctic Brown Algae. Phycologia, 46, 386-395. http://dx.doi.org/10.2216/06-67.1

[3] Grahan, L.E., Grahan, J.M. and Wilcox, L.W. (2009) Algae. 616 p.

[4] Gressler, V., Yokoya, N.S., Fujii, M.T., Colepicolo, P., Mancini Filho, J. and Torres, R.P. (2010) Lipid, Fatty Acid, Protein, Amino Acid and Ash Contents in Four Brazilian Red Algae Species. Food Chemistry, 120, 585-590. http://dx.doi.org/10.1016/j.foodchem.2009.10.028

[5] Gressler, V., Fujii, M.T., Martins, A.P., Colepicolo, P., Mancini-Filho, J. and Pinto, E. (2011) Biochemical Composition of Two Red Seaweed Species Grown on the Brazilian Coast. Journal of the Science of Food and Agriculture, 91, 1687-1692. http://dx.doi.org/10.1002/jsfa.4370

[6] McConnaughey, E. (1985) Sea Vegetables, Harvesting Guide \& Cookbook. 239 p.

[7] Ichimura, M., Kato, S., Tsuneyama, K., Matsutake, S., Kamogawa, M., Hirao, E., Miyata, A., Mori, S., Yamaguchi, N., Suruga, K., et al. (2013) Phycocyanin Prevents Hypertension and Low Serum Adiponectin Level in a Rat Model of Metabolic Syndrome. Nutrition Research, 33, 397-405. http://dx.doi.org/10.1016/j.nutres.2013.03.006

[8] Park, Y.K., Rasmussen, H.E., Ehlers, S.J., Blobaum, K.R., Lu, F., Schlegal, V.L., Carr, T.P. and Lee, J.Y. (2008) Repression of Proinflammatory Gene Expression by Lipid Extract of Nostoc Commune var Sphaeroides Kutzing, a BlueGreen Alga, via Inhibition of Nuclear Factor-Kappab in RAW 264.7 Macrophages. Nutrition Research, 28, 83-91. http://dx.doi.org/10.1016/j.nutres.2007.11.008

[9] Pereira, H., Barreira, L., Figueiredo, F., Custodio, L., Vizetto-Duarte, C., Polo, C., Resek, E., Engelen, A. and Varela, J. (2012) Polyunsaturated Fatty Acids of Marine Macroalgae: Potential for Nutritional and Pharmaceutical Applications. Marine Drugs, 10, 1920-1935. http://dx.doi.org/10.3390/md10091920

[10] Chan, Y.., Kim, K.H. and Cheah, S.H. (2011) Inhibitory Effects of Sargassum Polycystum on Tyrosinase Activity and Melanin Formation in B16F10 Murine Melanoma Cells. Journal of Ethnopharmacology, 137, 1183-1188. http://dx.doi.org/10.1016/j.jep.2011.07.050

[11] Liu, L., Heinrich, M., Myers, S. and Dworjanyn, S.A. (2012) Towards a Better Understanding of Medicinal Uses of the Brown Seaweed Sargassum in Traditional Chinese Medicine: A Phytochemical and Pharmacological Review. Journal of Ethnopharmacology, 142, 591-619. http://dx.doi.org/10.1016/j.jep.2012.05.046

[12] Quartino, M.L., Zaixso, H.E. and Boraso de Zaixso, A.L. (2005) Biological and Environmental Characterization of Marine Macroalgal Assemblages in Potter Cove, South Shetland Islands, Antarctica. Botanica Marina, 48, 187-197. http://dx.doi.org/10.1515/BOT.2005.029

[13] Quartino, M.L., Deregibus, D., Campana, G.L., Latorre, G.E. and Momo, F.R. (2013) Evidence of Macroalgal Colonization on Newly Ice-Free Areas Following Glacial Retreat in Potter Cove (South Shetland Islands), Antarctica. PLoS One, 8, e58223. http://dx.doi.org/10.1371/journal.pone.0058223

[14] Park, E.J. and Pezzuto, J.M. (2013) Antioxidant Marine Products in Cancer Chemoprevention. Antioxid Redox Signal, 19, 115-138. http://dx.doi.org/10.1089/ars.2013.5235 
[15] Yotsu-Yamashita, M., Kondo, S., Segawa, S., Lin, Y.C., Toyohara, H., Ito, H., Konoki, K., Cho, Y. and Uchida, T. (2013) Isolation and Structural Determination of Two Novel Phlorotannins from the Brown Alga Ecklonia Kurome Okamura, and Their Radical Scavenging Activities. Marine Drugs, 11, 165-183. http://dx.doi.org/10.3390/md11010165

[16] Zhang, Z., Teruya, K., Yoshida, T., Eto, H. and Shirahata, S. (2013) Fucoidan Extract Enhances the Anti-Cancer Activity of Chemotherapeutic Agents in MDA-MB-231 and MCF-7 Breast Cancer Cells. Marine Drugs, 11, 81-98. http://dx.doi.org/10.3390/md11010081

[17] Cardozo, K.H., Carvalho, V.M., Pinto, E. and Colepicolo, P. (2006) Fragmentation of Mycosporine-Like Amino Acids by Hydrogen/Deuterium Exchange and Electrospray Ionisation Tandem Mass Spectrometry. Rapid Communications in Mass Spectrometry, 20, 253-258. http://dx.doi.org/10.1002/rcm.2305

[18] Lacorte, S. and Fernandez-Alba, A.R. (2006) Time of Flight Mass Spectrometry Applied to the Liquid Chromatographic Analysis of Pesticides in Water and Food. Mass Spectrometry Reviews, 25, 866-880. http://dx.doi.org/10.1002/mas.20094

[19] El-Rafie, H.M., El-Rafie, M.H. and Zahran, M.K. (2013) Green Synthesis of Silver Nanoparticles Using Polysaccharides Extracted from Marine Macro Algae. Carbohydrate Polymers, 96, 403-410. http://dx.doi.org/10.1016/j.carbpol.2013.03.071

[20] Berteau, O. and Mulloy, B. (2003) Sulfated Fucans, Fresh Perspectives: Structures, Functions, and Biological Properties of Sulfated Fucans and an Overview of Enzymes Active toward This Class of Polysaccharide. Glycobiology, 13, 29R-40R. http://dx.doi.org/10.1093/glycob/cwg058

[21] Onofrejova, L., Vasickova, J., Klejdus, B., Stratil, P., Misurcova, L., Kracmar, S., Kopecky, J. and Vacek, J. (2010) Bioactive Phenols in Algae: The Application of Pressurized-Liquid and solid-Phase Extraction Techniques. Journal of Pharmaceutical and Biomedical Analysis, 51, 464-470. http://dx.doi.org/10.1016/j.jpba.2009.03.027

[22] WHO (2013) World Health Organization (Internet). http://www.who.int/en/

[23] Reichert, J.M. and Wenger, J.B. (2008) Development Trends for New Cancer Therapeutics and Vaccines. Drug Discovery Today, 13, 30-37. http://dx.doi.org/10.1016/j.drudis.2007.09.003

[24] Skrovankova, S. (2011) Seaweed Vitamins as Nutraceuticals. Advances in Food and Nutrition Research, 64, 357-369. http://dx.doi.org/10.1016/B978-0-12-387669-0.00028-4

[25] Khanavi, M., Nabavi, M., Sadati, N., Shams Ardekani, M., Sohrabipour, J., Nabavi, S.M., Ghaeli, P. and Ostad, S.N. (2010) Cytotoxic Activity of Some Marine Brown Algae against Cancer Cell Lines. Biological Research, 43, 31-37. http://dx.doi.org/10.4067/S0716-97602010000100005

[26] Yeh, C.C., Yang, J.I., Lee, J.C., Tseng, C.N., Chan, Y.C., Hseu, Y.C., Tang, J.Y., Chuang, L.Y., Huang, H.W., Chang, F.R., et al. (2012) Anti-Proliferative Effect of Methanolic Extract of Gracilaria tenuistipitata on Oral Cancer Cells Involves Apoptosis, DNA Damage, and Oxidative Stress. BMC Complementary and Alternative Medicine, 12, 142. http://dx.doi.org/10.1186/1472-6882-12-142

[27] Ryu, M.J., Kim, A.D., Kang, K.A., Chung, H.S., Kim, H.S., Suh, I.S., Chang, W.Y. and Hyun, J.W. (2013) The Green algae Ulva fasciata Delile Extract Induces Apoptotic Cell Death in Human Colon Cancer Cells. In Vitro Cellular \& Developmental Biology-Animal, 49, 74-81. http://dx.doi.org/10.1007/s11626-012-9547-3

[28] Li, Y., Qian, Z.J., Ryu, B., Lee, S.H., Kim, M.M. and Kim, S.K. (2009) Chemical Components and Its Antioxidant Properties in Vitro: An Edible Marine Brown Alga, Ecklonia cava. Bioorganic \& Medicinal Chemistry, 17, 1963-1973. http://dx.doi.org/10.1016/j.bmc.2009.01.031

[29] Yoon, J.S., Kasin Yadunandam, A., Kim, S.J., Woo, H.C., Kim, H.R., Kim, G.D. (2012) Dieckol, Isolated from Ecklonia stolonifera, Induces Apoptosis in Human Hepatocellular Carcinoma Hep3B Cells. Journal of Natural Medicines, 67, 519-527. http://dx.doi.org/10.1007/s11418-012-0709-0

[30] Jin, U.H., Lee, J.Y., Kang, S.K., Kim, J.K., Park, W.H., Kim, J.G., Moon, S.K. and Kim, C.H. (2005) A Phenolic Compound, 5-Caffeoylquinic Acid (Chlorogenic Acid), Is a New Type and Strong Matrix Metalloproteinase-9 Inhibitor: Isolation and Identification from Methanol Extract of Euonymus alatus. Life Sciences, 77, 2760-2769. http://dx.doi.org/10.1016/j.lfs.2005.02.028

[31] Belkaid, A., Currie, J.C., Desgagnes, J. and Annabi, B. (2006) The Chemopreventive Properties of Chlorogenic Acid Reveal a Potential New Role for the Microsomal Glucose-6-Phosphate Translocase in Brain Tumor Progression. Cancer Cell International, 6, 7. http://dx.doi.org/10.1186/1475-2867-6-7

[32] Feng, R., Lu, Y., Bowman, L.L., Qian, Y., Castranova, V. and Ding, M. (2005) Inhibition of Activator Protein-1, NF-kappaB, and MAPKs and Induction of Phase 2 Detoxifying Enzyme Activity by Chlorogenic Acid. The Journal of Biological Chemistry, 280, 27888-27895. http://dx.doi.org/10.1074/jbc.M503347200

[33] Kang, T.Y., Yang, H.R., Zhang, J., Li, D., Lin, J., Wang, L. and Xu, X. (2013) The Studies of Chlorogenic Acid Antitumor Mechanism by Gene Chip Detection: The Immune Pathway Gene Expression. Journal of Analytical Methods in 
Chemistry, 2013, Article ID: 617243. http://dx.doi.org/10.1155/2013/617243

[34] Kerr, J.F., Wyllie, A.H. and Currie, A.R. (1972) Apoptosis: A Basic Biological Phenomenon with Wide-Ranging Implications in Tissue Kinetics. British Journal of Cancer, 26, 239-257. http://dx.doi.org/10.1038/bjc.1972.33

[35] Ouyang, L., Shi, Z., Zhao, S., Wang, F.T., Zhou, T.T., Liu, B. and Bao, J.K. (2012) Programmed Cell Death Pathways in Cancer: A Review of Apoptosis, Autophagy and Programmed Necrosis. Cell Proliferation, 45, 487-498. http://dx.doi.org/10.1111/j.1365-2184.2012.00845.x

[36] Sola, S., Morgado, A.L. and Rodrigues, C.M. (2013) Death Receptors and Mitochondria: Two Prime Triggers of Neural Apoptosis and Differentiation. Biochimica et Biophysica Acta, 1830, 2160-2166. http://dx.doi.org/10.1016/j.bbagen.2012.09.021

[37] Kim, A.D., Lee, Y., Kang, S.H., Kim, G.Y., Kim, H.S. and Hyun, J.W. (2013) Cytotoxic Effect of Clerosterol Isolated from Codium Fragile on A2058 Human Melanoma Cells. Marine Drugs, 11, 418-430. http://dx.doi.org/10.3390/md11020418

[38] Schutte, B., Nuydens, R., Geerts, H. and Ramaekers, F. (1998) Annexin V Binding Assay as a Tool to Measure Apoptosis in Differentiated Neuronal Cells. Journal of Neuroscience Methods, 86, 63-69. http://dx.doi.org/10.1016/S0165-0270(98)00147-2

[39] van Engeland, M., Nieland, L.J., Ramaekers, F.C., Schutte, B. and Reutelingsperger, C.P. (1998) Annexin V-Affinity Assay: A Review on an Apoptosis Detection System Based on Phosphatidylserine Exposure. Cytometry, 31, 1-9. http://dx.doi.org/10.1002/(SICI)1097-0320(19980101)31:1<1::AID-CYTO1>3.0.CO;2-R

[40] de la Mare, J.A., Lawson, J.C., Chiwakata, M.T., Beukes, D.R., Edkins, A.L. and Blatch, G.L. (2012) Quinones and Halogenated Monoterpenes of Algal Origin Show Anti-Proliferative Effects against Breast Cancer Cells in Vitro. Investigational New Drugs, 30, 2187-2200. http://dx.doi.org/10.1007/s10637-011-9788-0

[41] Zhang, Z., Teruya, K., Eto, H. and Shirahata, S. (2013) Induction of Apoptosis by Low-Molecular-Weight Fucoidan through Calcium- and Caspase-Dependent Mitochondrial Pathways in MDA-MB-231 Breast Cancer Cells. Bioscience, Biotechnology, and Biochemistry, 77, 235-242.

[42] Hanahan, D. and Weinberg, R.A. (2011) Hallmarks of Cancer: The Next Generation. Cell, 144, 646-674. http://dx.doi.org/10.1016/j.cell.2011.02.013

[43] Tan, M.L., Ooi, J.P., Ismail, N., Moad, A.I. and Muhammad, T.S. (2009) Programmed Cell Death Pathways and Current Antitumor Targets. Pharmaceutical Research, 26, 1547-1560. http://dx.doi.org/10.1007/s11095-009-9895-1 